know a good deal more about the spectroscopy of this comparatively unknown group of substances. Fortunately most of the basic theory was alroady available, in Condon and Shortley's classic book, The Theory of Atomic Spectra, and with an extension to take account of crystal field effects, tho stage was set for rapid developments in the whole field of the spectroscopy of rare earth ions in solids. In fact, the developmont did not occur at all rapidly and even excursions into the actinide series did not attract a great deal of attention. Nevertheless a solid core of good work was dono, which has served as the foundation for the recent very exciting devolopments with rare earth solid-state lasers. Much remains to be done, of course, but with many moro physicists now engaged in understanding rare earth spectra there is a noed to be sure that the theoretical tochniques which are used are as powerful as possible.

Now the methods given in Condon and Shortley, and their crystal field extension, have served us well, but there is no doubt that they can be extromoly todious to use. Further, it commonly happens that the ond result of a lengthy calculation is quite simple, and one is left wondering whother or not there was a 'better way' of doing it. Well in many cases there was, and it is the purpose of this book to explain what we should have done.

Tho new method is based on the work of Prof. Racah, who examined in considerable depth the structure of many. electron wave-functions and their associated operators, using, particularly, group thooretical ideas. The result was a very elegant and instructive new way of dealing with problems in atomic spectroscopy, particularly those concerned with unfilled shells of olectrons of high orbital angular momonta. Unfortunately tho mathematical background is outside the range of knowledge of most spectroscopists, so that having coped with Condon and Shortloy they are now faced with an even less familiar field.

Prof. Judd writes extremely clearly and gives his reader every help, with lots of examples and illuminating comments. Even so there is littlo doubt that a typical rosponse will be to ask whether it is really necessary. The answer will of course depend a great deal on the reader, and the time which he is prepared to devote to what is really a large subject. The average experimental spectroscopist is probably best advised to leave this topic alone, unless he is a particularly good mathematician, though ho should certainly look through the book and try to obtain some feeling for the mathematical techniques which his theoretical colleagues are using. The theoretical spectroscopists, on the other hand, should delve much more deoply, for this is the modern way of dealing with manyelectron atoms, and here is ono of the principal exponents explaining it to them. They should, indeed, read care fully and thank Prof. Judd for loading them so smoothly into this comparatively difficult and unfamiliar branch of theoretical physics.

K. W. H. Stevens

\section{METALLURGY, ARCH/EOLOGY AND THE BRITISH ISLES}

\section{Metallurgy in Archaeology}

A Prehistory of Metallurgy in the British Isles. By Dr. R. F. Tylecote. Pp. xvi $+368+28$ plates. (London: Edward Arnold (Publishers) Ltd., 1962.) $84 s$.

"rT THE original object of this book was to gather I together the wealth of information on motallurgical aspects of archasology contained mainly in tho appendices to excavation roports. . . . It was not long before it became clear that the information available amounted to a prehistory of metallurgy in the British Isles," and it is to those Islands that the suthor's atten. tion is mainly, though by no means exclusivoly, directed. It will come as somowhat of a surprise to many readers to discover how great this woalth, in fact, is. In garnering in his harvest, Dr. Tylecote has performed a most valuablo service : between seven and oight hundred references to pertinent journals, many quito obscuro, are providod and the mere physical labour of making this colloction and visiting tho musoums and other sources of his material is beyond praise. In this work ho pays generous tribute to the help accorded by his wife. It must not, however, be assumed that this is a more catalogue; the information brought together has then boon sifted and welded into cohorency, a task for which the author, both a trainod engineer and motallurgist, is unusually well qualified to perform.

Starting with the native metals, and such gold as has beon recorded in England, Scotland, Wales and Irolanda nugget weighing $21.5 \mathrm{oz}$. was found in Ireland in the oightoenth century - the story is carried on to the final devolopment of the blast furnace and the production of molten iron around 1500 A.D. The earlier chapters, necessarily devoted to the non-ferrous metals, are concerned with copper and its alloys, the production of tin and tin alloys, lead and silver. How much work has in fact been done is demonstrated by the 22 pages of analyses of copper and bronze samples alone.

Motooric iron of indigenous origin is practically unknown in Great Britain, the Iron Age being introduced by Hallstatt poople from tho Continent probably between 500 and 400 B.c. It is reasonable to assume, therefore, that theso immigrants were already familiar with bollows. driven bowl furnaces, know something of the strengthening offect of carbon on iron, but were more or less ignorant of the technique of hardening carburized iron by waterquenching. After discussing the iron industry during the Roman occupation the author has a relatively short, but very important, chapter on iron during the 'Dark Ages' and the early medieval period. His conclusion is interest. ing. "In conclusion, we can say that there has been no advance on the pre-Roman techniques themselves, but that the knowledge of the processes of carburizing and heat-treatment is now more widespread" and "in certain cases brought together with great effect". In the AngloSaxon-Viking period "it would appoar that smolting and smithing techniquos carried on where the pro-Roman technique left off"'.

In the course of his discussion of pro-Roman iron. the author has collectod the available data relating to no less than 71 of the curious 'currency bars'. This information is subjected to a rough statistical analysis, the whole representing perhaps the most detailed discussion of these piocos yet availablo and amounting to a real and intensely interesting pioce of research.

Sandwiched in between the accounts of the non-ferrous materials and iron is the longest chapter in the book on methods of fabrication. This is a section of great velue and is outstandingly well done. Those whose curiosity is still unsatisfied will find, in the 151 reforonces, food for still more intonsive study. Hore, as indeed throughout the book, the sketches add immensely to the descriptions. Dotails of more than a hundred cruciblog found in the Islands, thoir provenance, dato, shupe and capacity, are given; analyses of typical slags, and descriptions of methods of manufacture of vessels are but part of the ground covered. Methods used in the manufacture of gold tores, how the late Bronze Ago sword was repairod, the way the Irish trumpot was constructod or the ressons why certain castings of a similar dato had had to be scrapped are examples of the range of problem discussed.

It would be too much to expect that at all points Dr. Tylocoto's viows coincido completely with thoso of any reviewer, but that this is a thoroughly reliable account, of a subjoct which bristles with difficultios there can be no doubt: the illustrations are excollently roproduced and the index all that the most exacting reader could nood. The labour which has gone into its proparation is immense and the result a work of outstanding value and interest.
F. C. ThoMpson 